\title{
Risk factors for falls in hospitalized adult patients: an integrative review
}

\author{
FATORES DE RISCO PARA QUEDAS EM PACIENTES ADULTOS HOSPITALIZADOS: \\ REVISÃO INTEGRATIVA
}

\section{FACTORES DE RIESGO DE CAÍDAS EN PACIENTES ADULTOS HOSPITALIZADOS: REVISIÓN INTEGRADORA DE LA LITERATURA}

\section{Isis Marques Severo', Miriam de Abreu Almeida², Ricardo Kuchenbecker ${ }^{3}$, Débora Feijó Villas Boas Vieira ${ }^{2}$, Michele Elisa Weschenfelder ${ }^{4}$, Luciana Ramos Corrêa Pinto ${ }^{4}$, Cristini Klein ${ }^{5}$, Ana Paula de Oliveira Siqueira ${ }^{6}$, Bruna Paulsen Panato ${ }^{7}$}

\begin{abstract}
Objective: Identifying risk factors for the occurrence of falls in hospitalized adult patients. Method: Integrative review carried out in the databases of LILACS, SCIELO, MEDLINE and Web of Science, including articles published between 1989 and 2012. Results: Seventy-one articles were included in the final sample. Risk factors for falls presented in this review were related to patients (intrinsic), the hospital setting and the working process of health professionals, especially in nursing (extrinsic). Conclusion: The systematic screening of risk factors for falls was identified as a contributing factor to the reduction of this injury, helping the nonoccurrence of this event that, despite being preventable, can have serious consequences including death.
\end{abstract}

\section{DESCRIPTORS}

Accidental falls

Inpatients

Hospitalization

Patient safety

Nursing care

Review

\section{RESUMO}

Objetivo: Identificar os fatores de risco para a ocorrência de quedas em pacientes adultos hospitalizados. Método: Revisão integrativa realizada nas bases de dados LILACS, SciELO, MEDLINE e Web of Science, abrangendo artigos publicados entre 1989 e 2012. Resultados: Setenta e um artigos compuseram a amostra final do estudo. Os fatores de risco para quedas apresentados nesta revisão foram relacionados ao paciente (intrínsecos), ao ambiente hospitalar e ao processo de trabalho dos profissionais da saúde, em especial à enfermagem (extrínsecos). Conclusão: A triagem sistemática de fatores de risco para queda foi identificada como fator contribuinte para a redução desse agravo, auxiliando a não ocorrência deste evento que, apesar de ser prevenível, pode determinar consequências graves incluindo o óbito.

\section{DESCRITORES \\ Acidentes por quedas \\ Pacientes internados \\ Hospitalização \\ Segurança do paciente \\ Cuidados de enfermagem \\ Revisão}

\begin{abstract}
RESUMEN
Objetivo: Identificar los factores de riesgo para la ocurrencia de caídas en pacientes adultos hospitalizados. Método: Revisión integradora de la literatura de artículos publicados entre los años 1989 al 2012 en las bases de datos LILACS, SciEIO, MEDLINE y Web of Science. Resultados: La muestra final estuvo compuesta por setenta y un artículos. Entre los factores de riesgo de caídas indicados en esta revisión están los relacionados con el paciente (intrínsecos), con el ambiente hospitalario y con el proceso de trabajo de los profesionales de la salud, especialmente enfermería (extrínsecos). Conclusión: La detección sistemática de factores de riesgo asociados a caídas fue identificada como un factor que contribuye a la reducción de este daño, favoreciendo de esta manera su no ocurrencia, la que a pesar de ser prevenible puede acarrear consecuencias graves, incluyendo la muerte.
\end{abstract}

\section{DESCRIPTORES \\ Accidentes por caídas Pacientes interno Hospitalización Seguridad del paciente Atención de enfermeira Revisión}

${ }^{1}$ PhD Student, Postgraduate Program in Nursing, Universidade Federal do Rio Grande do Sul, Porto Alegre, RS, Brazil. isismsevero@gmail.com ${ }^{2}$ Associate Professor, School of Nursing, Universidade Federal do Rio Grande do Sul, Porto Alegre, RS, Brazil. ${ }^{3}$ Professor of Epidemiology, Faculty of Medicine, Universidade Federal do Rio Grande do Sul, Porto Alegre, RS, Brazil. ${ }^{4}$ Nurse, Hospital de Clínicas of Porto Alegre, Porto Alegre, RS, Brazil. ${ }^{5}$ PhD Student, Postgraduate Program in Health Sciences, Universidade Federal do Rio Grande do Sul, Porto Alegre, RS, Brazil. ${ }^{6}$ MSc Student, Postgraduate Program in Nursing, Universidade Federal do Rio Grande do Sul, Porto Alegre, RS, Brazil. ${ }^{7}$ Undergraduate Nursing, School of Nursing, Universidade Federal do Rio Grande do Sul, Porto Alegre, RS, Brazil. 


\section{INTRODUCTION}

The falls of hospitalized patients have a striking effect on health due to the fact of being a problem related to patient safety, in addition to an issue for the quality of care in various health institutions in the world ${ }^{(1)}$. The falls occurred during hospitalization represent one of the most important instances of the lack of security, and are often responsible for the increase in number of hospitalization days and worse recovery of patients ${ }^{(2)}$.

The World Health Organization (WHO) defines a fall as inadvertently coming to rest on the ground or other lower level, excluding intentional change of position to lean on furniture, walls or other objects ${ }^{(3)}$.

The incidence of falls in the world varies depending on the studied population ${ }^{(4-6)}$. In 2007, the magnitude of this event in the United States of America (USA) showed that about one million patients had falls in hospitals ${ }^{(4)}$. In the years 2008 and 2009, in England and Wales, 283,438 thousand events were reported ${ }^{(5)}$. In 2004, in Australian hospitals, $17 \%$ of falls occurred in the elderly ${ }^{(6)}$.

In Brazil, in 2009, around 320 thousand hospitalizations occurred due to falls, which accounted for nearly $40 \%$ of total admissions due to external causes ${ }^{(7)}$. In the elderly, the national hospitalization rate for falls reached $27.6 \%$, that is similar to the data of the southern region $(26.9 \%)^{(8)}$.

Falls are responsible for two out of five adverse events in hospitals, and its frequency varies from 1.4 to 13.0 per every 1000 patients per day ${ }^{(4)}$. In general, these events aggravate health problems and the main consequences are trauma (fractures, for example); unscheduled removal of catheters, drains and probes; fear of falling again; emotional changes; clinical worsening; and even death. Such events may also increase the length of hospital stay and cost of treatment ${ }^{(9)}$.

In the U.S., the costs of treatment of falls totaled 19 billion dollars per year. England and Wales reached 15 million euros annually, which represents 92 million euros per year for every 800 beds $^{(10)}$. In Brazil, the expenses of the Unified Health System (SUS) with fractures due to falls in the elderly reached 81 million dollars per year ${ }^{(11)}$.

In the elderly, falls may decrease functional capacity, resulting in inability to perform activities of daily living. They may have consequences also for the family and health services, which need to mobilize for the treatment and recovery of this population ${ }^{(9)}$.

It is essential that health professionals identify the risk factors for falls in order to avoid this condition ${ }^{(1)}$. The measurement of the level of risk of patients may influence the choices of preventive interventions.

In clinical practice, there is the need to generate knowledge through studies with quantitative and qualitative approaches, not only regarding risk factors intrinsic to patients that are considered in models of prediction ${ }^{(1)}$, but also on extrinsic factors, which are commonly related to the outcome of falls.

Given the importance of adopting procedures that eliminate or reduce the risk of falls, a prior knowledge of which individuals have a higher probability for this event is necessary, from the identification of the complex relationship of its risk factors.

This study aimed to identify in the literature the risk factors for falls in hospitalized adult patients.

\section{METHOD}

This is an integrative literature review ${ }^{(12)}$, that groups the results obtained in research on a same subject. It was developed in five steps: problem formulation, data collection, data evaluation, analysis and interpretation of data and presentation of results. Its aim is the analysis and synthesis of data in order to develop a more comprehensive explanation of a particular phenomenon ${ }^{(12)}$. The formulation of the problem comprised the following research question: what are the risk factors for falls in hospitalized adult patients? The literature search was carried out in Portuguese, Spanish and English, including articles published from 1989 to October 2012. The time frame was defined based on the publication of the first predictive model for falls ${ }^{(13)}$, in 1989.

In the review were only included the studies in which the scenario was represented by units of clinical and surgical adult hospitalization because these depict the higher prevalence of the event ${ }^{(4-5)}$. And also studies that answered the research question, selected by title and abstract of the articles. Publications repeated in more than a database were analyzed only once.

The searched database were the Latin-American and Caribbean Center on Health Sciences Information (LILACS), Scientific Eletronic Library Online (SciELO), MEDLINE and Web of Science, considering the following descriptors: accidental falls, hospitalization, patient safety, risk assessment, nursing process, nursing diagnosis. The keywords falls and hospital were also used adapting to the language, in accordance with the database.

For the data analysis was used a synoptic table containing variables that answered the research question of the study. The topics of interest were: article title, authors, year of publication, location of the study, journal, method, population/sample, results/risk factors of falls.

Figure 1 outlines the process of selecting the articles, starting with the grouping of descriptors, consulted databases, the number of articles that answered the research question and the number of articles selected according to the inclusion criteria. It is noteworthy that the items identified in LILACS are also indexed in SciELO.
Risk factors for falls in hospitalized adult patients: an integrative review 

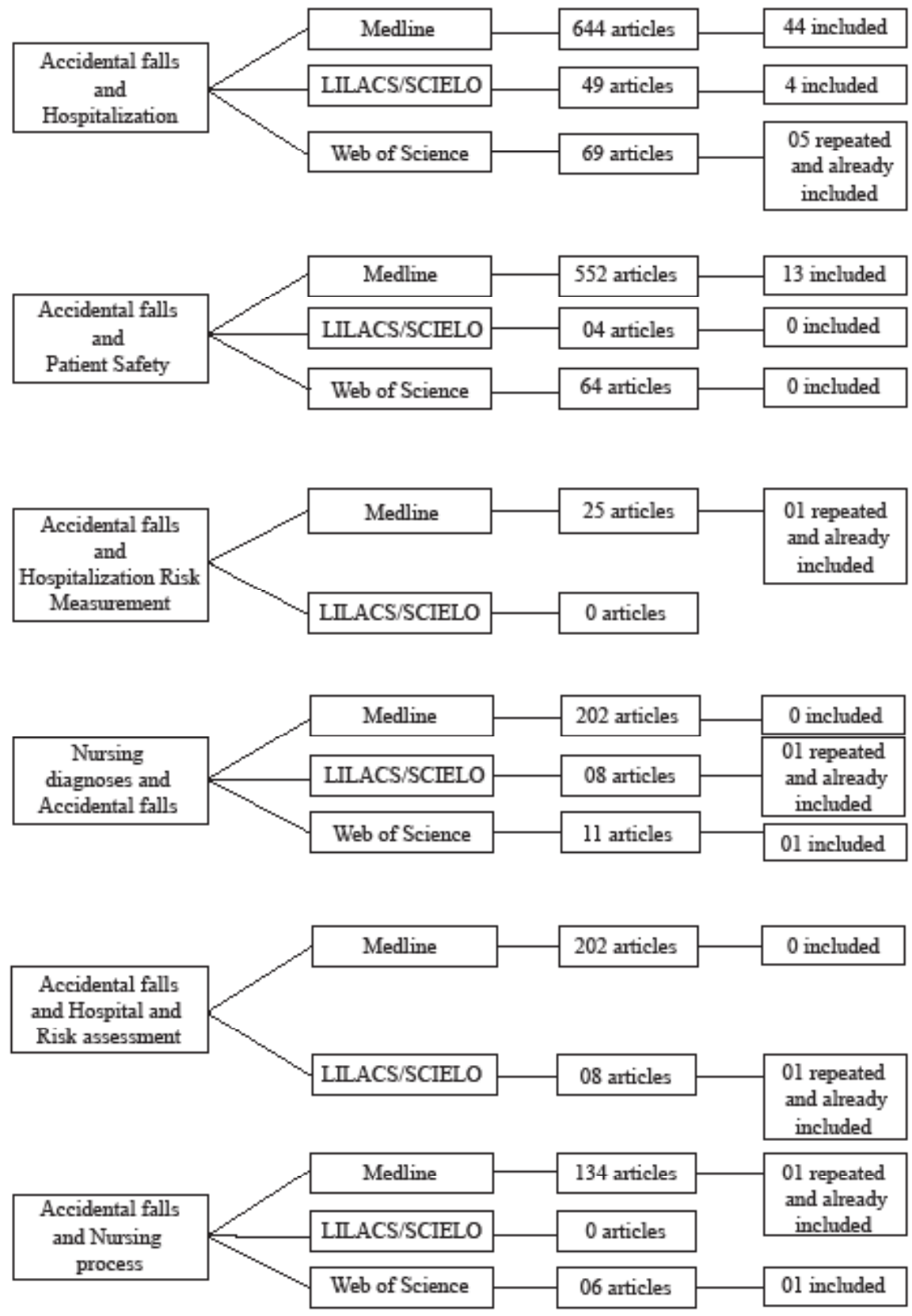

Figure 1 -Selection of articles by grouping of descriptors in databases. Porto Alegre, RS, 2012.

\section{RESULTS}

The countries of publication of studies that comprised the sample $(n=71)$ were: United States of America (USA), 23 (32.3\%); Australia, eight (11.2\%); United Kingdom, seven (9.8\%); Switzerland, six (8.4\%); Israel, five (7\%); Canada and China, with four each (5.6\%); Brazil, three (4.2\%); Japan, two (2.8\%); Bosnia, Portugal, Egypt, Singapore, Colombia, Germany, Italy, Turkey and Serbia had one study each (1.4\%).

From the selected studies, Table 1 shows the characterization of the sample according to the period of publication.
Table 1 - Sample distribution by period of publication - Porto Alegre, RS, 2012

\begin{tabular}{cc}
\hline Period of publication & $\mathbf{N}(\%)$ \\
\hline $1989-1999$ & 0 \\
$1999-2001$ & $1(1.4)$ \\
$2001-2003$ & $2(2.8)$ \\
$2003-2005$ & $14(19.7)$ \\
$2005-2007$ & $6(8.4)$ \\
$2007-2009$ & $11(15.4)$ \\
$2009-2011$ & $16(22.5)$ \\
2011 H 2012 & $21(29.5)$ \\
\hline Total & $71(100)$ \\
\hline
\end{tabular}


The distribution of the sample was carried out according to the types of studies: cross-sectional studies, 23 (32.3\%); cohort, 19 (26.7\%); case-control studies, nine $(12.7 \%)$; literature review, $10(14.4 \%)$; randomized controlled trials, five (7.0\%); qualitative studies, two (2.8\%); and systematic reviews, three (4.2\%).

Chart 1 presents the different types of study of this integrative review summarized, showing the evolution of knowledge about the topic of study.

Chart 1 - Summary of studies and its risk factors - Porto Alegre, RS, 2012

\begin{tabular}{|c|c|c|c|c|}
\hline Year & $\begin{array}{l}\text { (Study) } \\
\text { Country }\end{array}$ & $\begin{array}{c}\text { Design/ } \\
\text { Number of patients }\end{array}$ & Interventions & $\begin{array}{c}\text { Risk factor/Relative risk (RR) or Odds ratio (OR)/Confidence } \\
\text { interval (CI) } 95 \% \text { and/or p-value }\end{array}$ \\
\hline 1999 & $\begin{array}{l}(14) \\
\text { China }\end{array}$ & $\begin{array}{l}\text { Case-control } \\
\text { Cases } n=51 / \\
\text { Controls } n=51\end{array}$ & $\begin{array}{l}\text { Tests to assess the progress of } \\
\text { patients as a way to track the } \\
\text { risk of falls. }\end{array}$ & $\begin{array}{l}\text { Previous falls, active neoplasia, mobility problems, weakness of } \\
\text { the lower limbs, postural hypotension, disorientation, drugs (seda- } \\
\text { tives, hypnotics and antidepressants) showed }<<0.05 \text {. }\end{array}$ \\
\hline \multirow[b]{2}{*}{2001} & $\begin{array}{l}(15) \\
\text { Switzer- } \\
\text { land }\end{array}$ & $\begin{array}{c}\text { Cross-sectional } \\
\mathrm{n}=26.643\end{array}$ & $\begin{array}{l}\text { Characterization of falls as a } \\
\text { form of research. }\end{array}$ & $\begin{array}{l}2.7 \text { falls/ } 1000 \text { patients-day. Higher incidence in patients with } \\
\text { comorbidities and aged over } 45 \text { years (especially after } 75 \text { years). }\end{array}$ \\
\hline & $\begin{array}{l}(16) \\
\text { Brazil }\end{array}$ & Qualitative & $\begin{array}{l}\text { Identification of the knowledge } \\
\text { of } 14 \text { nurses on the predisposing } \\
\text { factors for falls. }\end{array}$ & $\begin{array}{l}\text { Intrinsic risk factors: confusion/disorientation, decreased mobil- } \\
\text { ity, weakness, old age, visual impairment; diseases: cancer, heart } \\
\text { disease, neuropathy (100\%), drowsiness and hypotension (71.4\%). } \\
\text { Environmental risk factors: high beds }(92.8 \%) \text {, wet floor }(85.7 \%) \\
\text { and hazardous locations (wards and bathroom) }(78.6 \%) \text {. Risk fac- } \\
\text { tors of therapy: antihypertensives and diuretics, sedatives, tranquil- } \\
\text { izers and hypnotics }(85.7 \%) \text { and medication side effects }(71.4 \%) \text {. }\end{array}$ \\
\hline \multirow[b]{2}{*}{2003} & $\begin{array}{l}(17) \\
\text { Israel }\end{array}$ & $\begin{array}{l}\text { Case-control } \\
\text { Trocanter group } n=52 / \\
\text { Diverse group } n=49\end{array}$ & $\begin{array}{l}\text { Implementation of preventive } \\
\text { measures. }\end{array}$ & $\begin{array}{l}\text { Only age (years }+-\mathrm{SD}) \text { was considered statistically significant } \\
(\mathrm{p}=0.0482) \text { : trocanter group } 77.3+-8.4 \text { and diverse group } 80.4+-6.7 \text {. }\end{array}$ \\
\hline & $\begin{array}{c}(18) \\
\text { Austrália }\end{array}$ & $\begin{array}{l}\text { Cross-sectional } \\
\quad \mathrm{n}=91\end{array}$ & $\begin{array}{l}\text { Identification of extrinsic risk } \\
\text { factors in the prevention of falls. }\end{array}$ & $\begin{array}{l}\text { Greater number of falls during the day, with peaks at times of shift } \\
\text { change. } n=40(44) \text { of the patients who fell have suffered harm } \\
\text { such as pain, bruising or laceration, in addition to doing X-rays } \\
\text { and CT scans. There were no fractures and deaths }\end{array}$ \\
\hline \multirow{6}{*}{2004} & $\begin{array}{c}(19) \\
\text { Austrália }\end{array}$ & $\begin{array}{l}\text { Case-control } \\
\text { Cases } n=15 / \\
\text { Controls } n=73\end{array}$ & $\begin{array}{l}\text { Use of screening protocols of } \\
\text { patients at admission. }\end{array}$ & $\begin{array}{l}\text { Mini mental < } 7 \text { (5.03; CI 95\%:1.52-16.57); cerebrovascular ac- } \\
\text { cident (CVA) (4.36; CI 95\%:1.70-11.20); previous falls (3.0; CI } \\
95 \%: 1.25-7.23) \text {; confusion or delirium (2.89; CI 95\%:1.18-7.08); } \\
\text { fall and confusion or delirium (5.60; CI 95\%: } 1.95-16.06), \mathrm{p}<0.05 \text {. } \\
\text { More than two risk factors adjusted for age, gender and length of } \\
\text { hospitalization (8.17; CI 95\%:1.96-34.06). }\end{array}$ \\
\hline & $\begin{array}{l}(20) \\
\text { EUA }\end{array}$ & $\begin{array}{l}\text { Case-control } \\
\text { Cases } n=90 / \\
\text { Controls } n=90\end{array}$ & $\begin{array}{l}\text { Use of information system in } \\
\text { the patient safety. }\end{array}$ & $\begin{array}{l}\text { Previous falls; female gender; difficulty in gait; cognitive disorders } \\
\text { and use of one or more sedative. Sensitivity of } 67.4 \% \text { and specific- } \\
\text { ity of } 60 \% \text {. }\end{array}$ \\
\hline & $\begin{array}{l}(21) \\
\text { EUA }\end{array}$ & $\begin{array}{l}\text { Cross-sectional } \\
\quad \mathrm{n}=6402\end{array}$ & $\begin{array}{l}\text { Development of a fall preven- } \\
\text { tion program using a computer } \\
\text { system. }\end{array}$ & $\begin{array}{l}\text { Risk factor divided into categories: Activity - age }>70 \text { years; } \\
\text { hearing/vision; assisted transfer; change in activity/mobility. } \\
\text { Disorientation - mental deterioration; cognitive impairment; age } \\
>70 \text { years; medication and hearing/vision. After-medication - } \\
\text { medication; age }>70 \text { years; pain; change in activity/mobility. Toilet } \\
\text { - incontinence; urinary problems, hearing/vision; intravenous } \\
\text { therapy and constipation. }\end{array}$ \\
\hline & $\begin{array}{l}(22) \\
\text { EUA }\end{array}$ & $\begin{array}{l}\text { Cross-sectional } \\
\text { Admissions in a three } \\
\text { month period (1300 } \\
\text { hospital beds) }\end{array}$ & $\begin{array}{l}\text { Characterization of falls in the } \\
\text { hospital as a form of research. }\end{array}$ & $\begin{array}{l}183 \text { patients suffered falls. The average age of those who fell was } \\
63.4 \text { years (range } 17-96) .50 \% \text { of falls were related to disposal and } \\
\text { to patients aged over } 65 \text { years }(\mathrm{p}<0.001) \text {. The clinical and neurol- } \\
\text { ogy units }(6.12 \text { falls } / 1000 \text { patient-day) had a higher number of } \\
\text { patients/nurse ( } 6.5 \text { and } 5.3 \text { respectively) and showed higher rates } \\
\text { of the event. }\end{array}$ \\
\hline & $\begin{array}{l}(23) \\
\text { Canadá }\end{array}$ & $\begin{array}{l}\text { Prospective cohort } \\
n=133\end{array}$ & $\begin{array}{l}\text { Identification of complications } \\
\text { falls to management. }\end{array}$ & Falls have occurred in $20 \%$ of the sample of survivors of CVA. \\
\hline & $\begin{array}{l}(24) \\
\text { Canadá }\end{array}$ & $\begin{array}{c}\text { Cross-sectional } \\
\mathrm{n}=1926\end{array}$ & $\begin{array}{l}\text { Characterization of falls with } \\
\text { hip fracture. }\end{array}$ & $\begin{array}{l}\text { The number of falls was higher in all age groups of females. Surgi- } \\
\text { cal patients suffer more hip fractures than clinical patients when } \\
\text { they are hospitalized. }\end{array}$ \\
\hline
\end{tabular}




\begin{tabular}{|c|c|c|c|c|}
\hline \multicolumn{5}{|c|}{..Continuation } \\
\hline Year & $\begin{array}{l}\text { (Study) } \\
\text { Country }\end{array}$ & $\begin{array}{l}\text { Design// } \\
\text { Number of patients }\end{array}$ & Interventions & $\begin{array}{c}\text { Risk factor/Relative risk (RR) or Odds ratio (OR)/Confidence } \\
\text { interval (CI) } 95 \% \text { and/or p-value }\end{array}$ \\
\hline \multirow{5}{*}{2004} & $\begin{array}{l}(25) \\
\text { Israel }\end{array}$ & $\begin{array}{l}\text { Cross-sectional } \\
\text { Admissions ( } 2000 \\
\text { hospital beds) }\end{array}$ & $\begin{array}{l}\text { Enhancement of a surveillance } \\
\text { system for falls. }\end{array}$ & $\begin{array}{l}\text { The most frequent causes of falls were weakness, dizziness/poor } \\
\text { balance, slip, confusion and amnesia. Increased prevalence of } \\
\text { falls attributed to the demand for hospital care and increase of the } \\
\text { surveillance system with higher notification. }\end{array}$ \\
\hline & $\begin{array}{l}\text { (26) } \\
\text { United } \\
\text { Kingdom }\end{array}$ & Literature review & $\begin{array}{l}\text { Observation and monitoring of } \\
\text { patients with cognitive impair- } \\
\text { ment }\end{array}$ & $\begin{array}{l}\text { The architecture of the units blocking the visibility of beds, } \\
\text { scheduled tasks that require closing the curtains or leaving the } \\
\text { bed edge area to perform other activities. Major risk factors for } \\
\text { patients: unsteadiness of gait, weakness of the lower limbs, uri- } \\
\text { nary incontinence/frequency or needing help to go to the toilet, } \\
\text { history of falls, agitation/confusion or impaired judgment, use } \\
\text { of medications (benzodiazepines, psychotropic drugs, antiar- } \\
\text { rhythmics, digoxin, diuretics, sedatives and more than four drugs } \\
\text { regardless of type) }\end{array}$ \\
\hline & $\begin{array}{l}(27) \\
\text { United } \\
\text { Kingdom }\end{array}$ & Systematic review & $\begin{array}{l}\text { Identification of publications on } \\
\text { risk factors and risk assessment } \\
\text { tools for falls. }\end{array}$ & $\begin{array}{l}\text { Significant risk factors: unsteadiness to walk, weakness of the } \\
\text { lower limbs, urinary incontinence/frequency or needing help to go } \\
\text { to the toilet, history of falls, agitation/confusion/impaired judg- } \\
\text { ment, sedatives and hypnotics. }\end{array}$ \\
\hline & $\begin{array}{l}(28) \\
\text { United } \\
\text { Kingdom }\end{array}$ & $\begin{array}{l}\text { Randomized } \\
\text { clinical trial }\end{array}$ & $\begin{array}{l}\text { Multidisciplinary team acting } \\
\text { on risk factors }\end{array}$ & $\begin{array}{l}\text { Control group had a higher rate of falls }(\mathrm{p}=0.033) \text {, permanent } \\
\text { injury }(\mathrm{p}=0.025) \text {, and total falls }(\mathrm{p}=0.045) \text {. The results lose } \\
\text { statistical significance when controlled for different times of } \\
\text { hospitalization. }\end{array}$ \\
\hline & $\begin{array}{c}(29) \\
\text { Austrália }\end{array}$ & $\begin{array}{l}\text { Randomized } \\
\text { clinical trial }\end{array}$ & $\begin{array}{l}\text { Evaluation of efficacy of the } \\
\text { interventions of a prevention } \\
\text { program. }\end{array}$ & $\begin{array}{l}\text { The intervention group }(\mathrm{n}=310) \text { had } 30 \% \text { fewer falls than the } \\
\text { control group }(\mathrm{n}=316) \text {. This difference was significant }(\mathrm{p}=0.045) \\
\text { after } 45 \text { days of observation. In the intervention group there was a } \\
\text { reduction of falls }(0.78 \text {; CI } 95 \%: 0.56-1.06) \text { and } 28 \% \text { fewer events } \\
\text { resulted in injuries }(\mathrm{p}=0.20) \text {. }\end{array}$ \\
\hline \multirow{2}{*}{2005} & $\begin{array}{l}(30) \\
\text { Italy }\end{array}$ & $\begin{array}{l}\text { Prospective cohort } \\
\qquad \mathrm{n}=13.729\end{array}$ & $\begin{array}{l}\text { Tracing of patients at risk of } \\
\text { geriatric syndrome. }\end{array}$ & $\begin{array}{l}\text { Age }>85 \text { years }(1.8 \text {; CI 95\%:1.2-2.8); cognitive impairment and } \\
\text { length of hospital stay > three weeks (1.6; CI 95\%: } 1.2-2.3) \text {. } \\
\text { Independent factors: previous falls (8.1; CI 95\%: 6.1-10.8); neuro- } \\
\text { leptics (2.1; CI 95\%: 1.4-3.0) and benzodiazepines (1.9; CI 95\%: } \\
1.4-2.5) \text {. }\end{array}$ \\
\hline & $\begin{array}{l}(31) \\
\text { EUA }\end{array}$ & $\begin{array}{l}\text { Case-control } \\
\text { Cases } \mathrm{n}=62 / \\
\text { Controls } \mathrm{n}=62\end{array}$ & $\begin{array}{l}\text { Appraisal of drugs and history } \\
\text { of dementia in the prevention } \\
\text { of falls. }\end{array}$ & $\begin{array}{l}\text { Patients in the case group received more medication than the } \\
\text { control group } 24 \text { hours before the event }(\mathrm{p}<0.003) \text {, dementia } \\
(\mathrm{p}=0.021) \text {, non-steroidal anti-inflammatory and drugs that can in- } \\
\text { duce sedation or postural hypotension were significant risk factors. }\end{array}$ \\
\hline \multirow{3}{*}{2006} & $\begin{array}{l}(32) \\
\text { United } \\
\text { Kingdom }\end{array}$ & $\begin{array}{l}\text { Prospective cohort } \\
\quad \mathrm{n}=1025\end{array}$ & $\begin{array}{l}\text { Evaluation of the medical } \\
\text { prescription }\end{array}$ & $\begin{array}{l}\text { Confused patients (0.38; CI 95\%: 0.29-0.49; } \mathrm{p}<0.0001) \text {, use of } \\
\text { tranquilizers (0.63; CI 95\%: 0.49-0.82; }<0.001) \text {. }\end{array}$ \\
\hline & $\begin{array}{l}(33) \\
\text { Switzer- } \\
\text { land }\end{array}$ & $\begin{array}{l}\text { Cross-sectional } \\
\quad \mathrm{n}=34972\end{array}$ & $\begin{array}{l}\text { Implementation of a prevention } \\
\text { program. }\end{array}$ & $\begin{array}{l}3842 \text { falls. Significant risk factors for falls: impaired physical } \\
\text { mobility and cognition, history of falls, narcotics and psychotropic } \\
\text { substances. }\end{array}$ \\
\hline & $\begin{array}{l}(34) \\
\text { Canada }\end{array}$ & $\begin{array}{l}\text { Retrospective cohort } \\
\qquad \mathrm{n}=1267\end{array}$ & $\begin{array}{l}\text { Interventions preventive of falls } \\
\text { for patients with lower limb } \\
\text { amputation. }\end{array}$ & $\begin{array}{l}\text { 10.3/1000 patients-day. Age }>71 \text { years (OR } 1.40 \text { ), hospital stay } \\
\text { of } 22-35 \text { days (OR 2.97) or five weeks (OR 6.07), four or more } \\
\text { comorbidities (OR 1.93), cognitive disorder (OR 1.68), two or } \\
\text { more drugs if necessary (OR 1.81), benzodiazepines (OR 2.22), } \\
\text { and opioids (OR 5.76); p<0.05. }\end{array}$ \\
\hline \multirow[b]{2}{*}{2007} & $\begin{array}{l}(35) \\
\text { Israel }\end{array}$ & $\begin{array}{l}\text { Case-control } \\
\text { Cases } n=84 / \\
\text { Controls } n=84\end{array}$ & $\begin{array}{l}\text { Prevention from the classifica- } \\
\text { tion of patients by diagnosis. }\end{array}$ & $\begin{array}{l}100 \text { falls. There was no difference in the frequency of falls be- } \\
\text { tween groups of patients. The variables with p }<0.05 \text { were: use of } \\
\text { wheelchair, proximity of the bed and risky activity. }\end{array}$ \\
\hline & $\begin{array}{l}(36) \\
\text { EUA }\end{array}$ & Literature review & $\begin{array}{l}\text { Identification of falls in hospi- } \\
\text { talized patients with cancer in } \\
\text { the literature. }\end{array}$ & $\begin{array}{l}\text { Old fractures, muscle weakness, history of falls, gait and balance } \\
\text { disorders, agitation, confusion/delirium, frequent trips to the } \\
\text { bathroom for urinary incontinence or urgency, visual impair- } \\
\text { ment, difficulty in transfers, dizziness, drugs (sedatives/hypnotics, } \\
\text { anticonvulsants, antihistamines, diuretics), increased patient-nurse } \\
\text { relationship. }\end{array}$ \\
\hline
\end{tabular}

Continued... 


\begin{tabular}{|c|c|c|c|c|}
\hline Year & $\begin{array}{l}\text { (Study) } \\
\text { Country }\end{array}$ & $\begin{array}{l}\text { Design/ } \\
\text { Number of patients }\end{array}$ & Interventions & $\begin{array}{c}\text { Risk factor/Relative risk (RR) or Odds ratio (OR)/Confidence } \\
\text { interval (CI) } 95 \% \text { and/or p-value }\end{array}$ \\
\hline 2007 & $\begin{array}{l}(37) \\
\text { United } \\
\text { Kingdom }\end{array}$ & Literature review & $\begin{array}{l}\text { General review of falls in the } \\
\text { elderly. }\end{array}$ & $\begin{array}{l}\text { Risk factors: age }>85 \text { years; use of medication (benzodiazepines, } \\
\text { diuretics, laxatives, sedatives/hypnotics, vasodilators, antihyper- } \\
\text { tensives and antidepressants); altered mental status; incontinence } \\
\text { and environmental factors. }\end{array}$ \\
\hline \multirow{7}{*}{2008} & $\begin{array}{l}\text { (38) } \\
\text { Switzer- } \\
\text { land }\end{array}$ & $\begin{array}{l}\text { Prospective cohort } \\
\qquad \mathrm{n}=34972\end{array}$ & $\begin{array}{l}\text { Interventions according to pa- } \\
\text { tient risk and the characteristics } \\
\text { of the unit. }\end{array}$ & $\begin{array}{l}\text { The identified risk factors were: changes in mobility and cognition, } \\
\text { history of falls, use of narcotics and psychotropic substances, } \\
\text { changes in eliminations; use of the bathroom and visual decline. }\end{array}$ \\
\hline & $\begin{array}{l}(39) \\
\text { Switzer- } \\
\text { land }\end{array}$ & $\begin{array}{l}\text { Cross-sectional } \\
\quad \mathrm{n}=57\end{array}$ & Gait assessment on admission. & $\begin{array}{l}\text { Only the coefficient of variation of the time of steps during the } \\
\text { walk was significantly associated with the occurrence of the first } \\
\text { fall event }(p=0.006)\end{array}$ \\
\hline & $\begin{array}{l}(40) \\
\text { Israel }\end{array}$ & $\begin{array}{l}\text { Prospective cohort } \\
\quad \mathrm{n}=1128\end{array}$ & $\begin{array}{l}\text { Implementation of a predictive } \\
\text { model. }\end{array}$ & $\begin{array}{l}\text { Previous falls (3.8; CI 95\%: } 2.65-5.45 ; \mathrm{p}<0.0001 \text { ) and impaired } \\
\text { mobility (1.56; CI95\%: } 1.06-2.29, \mathrm{p}<0.05) \text {. Sensitivity: } 67 \% \text {, } \\
\text { specificity: } 63 \% \text {. }\end{array}$ \\
\hline & $\begin{array}{l}(41) \\
\text { EUA }\end{array}$ & $\begin{array}{l}\text { Retrospective cohort } \\
\qquad \mathrm{n}=1472\end{array}$ & $\begin{array}{l}\text { Measurement of functional } \\
\text { independence score during } \\
\text { rehabilitation. }\end{array}$ & $\begin{array}{l}9.5 \% \text { falls. } 74 \% \text { were not observed. Risk factors: low cognitive } \\
\text { score at admission } 0.98(0.96-1.00) 0.019 \text {; CVA } 1.79(1.22-2.63) \\
0003 \text {; amputation } 3.0(2.20-6.57) 0.000 \text {; age } 41-50 \text { years } 2.01 \\
(1.31-3.07) 0.001 \text { e multiple comorbidities } 1.50(1.09-2.07) 0.014 \text {. }\end{array}$ \\
\hline & $\begin{array}{l}(42) \\
\text { EUA }\end{array}$ & $\begin{array}{l}\text { Cross-sectional } \\
\quad \mathrm{n}=32\end{array}$ & $\begin{array}{l}\text { Height of bed as prevention of } \\
\text { falls and its consequences. }\end{array}$ & $\begin{array}{l}188 \text { measurements were done. During the weekends the height of } \\
\text { the beds remained higher when compared to weekdays. }\end{array}$ \\
\hline & $\begin{array}{l}(43) \\
\text { EUA }\end{array}$ & Literature review & $\begin{array}{l}\text { Description of drugs that are } \\
\text { associated with falls. }\end{array}$ & $\begin{array}{l}\text { The use of benzodiazepines, cardiovascular agents and antidepres- } \\
\text { sants in the elderly is considered a risk factor for falls. }\end{array}$ \\
\hline & $\begin{array}{l}(44) \\
\text { EUA }\end{array}$ & Literature review & $\begin{array}{l}\text { Management of medications in } \\
\text { order to reduce falls. }\end{array}$ & $\begin{array}{l}\text { The use of anticoagulants, anticonvulsants, anticholinergics and } \\
\text { antipsychotropic drugs in the elderly is considered a risk factor for } \\
\text { falls. }\end{array}$ \\
\hline \multirow{4}{*}{2009} & $\begin{array}{l}(45) \\
\text { EUA }\end{array}$ & $\begin{array}{l}\text { Cross-sectional } \\
\quad \mathrm{n}=252\end{array}$ & $\begin{array}{l}\text { Recognition of delirium and } \\
\text { mental status changes. }\end{array}$ & $\begin{array}{l}\text { Delirium (previously diagnosed or not); age }>70 \text { years; ambulatory } \\
\text { and gastrointestinal procedures were associated with falls. }\end{array}$ \\
\hline & $\begin{array}{l}(46) \\
\text { EUA }\end{array}$ & $\begin{array}{l}\text { Cross-sectional } \\
\quad \mathrm{n}=91\end{array}$ & $\begin{array}{l}\text { Discussion about measures of } \\
\text { fall prevention. }\end{array}$ & $\begin{array}{l}31.9 \% \text { of patients with difficulty in self-care, } 41.8 \% \text { fell at home } \\
\text { before hospitalization and } 53.8 \% \text { had the bed at home at a lower } \\
\text { height than in the hospital. }\end{array}$ \\
\hline & $\begin{array}{l}(47) \\
\text { China }\end{array}$ & $\begin{array}{c}\text { Case-control } \\
\text { Cases }=202 / \\
\text { Controls } \mathrm{n}=202\end{array}$ & $\begin{array}{l}\text { Identification of risk factors of } \\
\text { hospitalized patients }\end{array}$ & $\begin{array}{l}\text { Insomnia }(0.28 ; \text { CI } 95 \%: 1.06-4.89), p=0.03 \text {; weakness in legs } \\
(1.88 ; \text { CI } 95 \%: 1.16-3.05), p=0.01 ; \text { postural hypotension }(5.75 \\
\text { CI } 95 \%: 1.54-21.46), p=0.01 ; \text { prior history of fall }(5.05 ; \text { CI } 95 \% \text { : } \\
\text { 2.60-9.78), } \mathrm{p}<0.001 \text { and hypnotics }(1.86 ; \text { CI } 95 \%: 1.10-3.14), \mathrm{p}= \\
0.02 \text {. Fewer falls: full-time caregiver }(0.51 ; \text { CI } 95 \%: 0.33-0.78) \text {, } \\
\mathrm{p}<0.001 \text {. }\end{array}$ \\
\hline & $\begin{array}{l}(48) \\
\text { Serbia }\end{array}$ & Literature review & $\begin{array}{l}\text { General review of risk factors } \\
\text { for falls }\end{array}$ & $\begin{array}{l}\text { Risk factors: mental confusion, history of falls, use of sedatives/ } \\
\text { hypnotics, extremes of age, needing help with self-care. There } \\
\text { is an inverse association of high workload and low professional } \\
\text { qualification with increased rates of falls. }\end{array}$ \\
\hline \multirow{3}{*}{2010} & $\begin{array}{l}(49) \\
\text { Israel }\end{array}$ & $\begin{array}{l}\text { Cross-sectional } \\
\quad \mathrm{n}=41\end{array}$ & $\begin{array}{l}\text { Characterization of falls oc- } \\
\text { curred in hospitalized patients } \\
\text { for rehabilitation after CVA. }\end{array}$ & $\begin{array}{l}56 \text { falls. Patients with hemiplegia fell more times than those with } \\
\text { hemiparesis }(\mathrm{p}=0: 04) .48 \% \text { of falls occurred during the first } \\
\text { month after the CVA. } 89 \% \text { of those who fell were using hypogly- } \\
\text { cemic agents, antihypertensive, tranquilizers or neuroleptics. } 29 \% \\
\text { had communication problems and } 21 \% \text { had decreased vision or } \\
\text { blindness. }\end{array}$ \\
\hline & $\begin{array}{l}(50) \\
\text { Japan }\end{array}$ & $\begin{array}{l}\text { Cross-sectional } \\
\text { Young adults } n=22 \\
\text { Elderly } n=19\end{array}$ & $\begin{array}{l}\text { Identification of risk factors re- } \\
\text { lated to the use of the bathroom } \\
\text { at night. }\end{array}$ & $\begin{array}{l}\text { The study suggests that gait and visual changes are risk factors for } \\
\text { falls. }\end{array}$ \\
\hline & $\begin{array}{l}(51) \\
\text { EUA }\end{array}$ & $\begin{array}{l}\text { Retrospective cohort } \\
\quad \mathrm{n}=1269\end{array}$ & Use of a severity score for CVA. & $\begin{array}{l}\text { Prevalence of falls: } 5 \%(65 / 1,269) .56 \% \text { were men aged }>65 \text { years } \\
(71.21 \mathrm{SD}+-13.30 \text { years). Moderate to severe brain ischemia } \\
(\mathrm{p}=0.03) \text {; previous history of anxiety }(\mathrm{p}<0.001) \text { and urinary tract } \\
\text { infection }(\mathrm{p}=0.05) \text {. }\end{array}$ \\
\hline
\end{tabular}

Continued...

Risk factors for falls in hospitalized adult patients: an integrative review 


\begin{tabular}{|c|c|c|c|c|}
\hline \multicolumn{5}{|c|}{...Continuation } \\
\hline Year & $\begin{array}{l}\text { (Study) } \\
\text { Country }\end{array}$ & $\begin{array}{l}\text { Design/ } \\
\text { Number of patients }\end{array}$ & Interventions & $\begin{array}{c}\text { Risk factor/Relative risk (RR) or Odds ratio (OR)/Confidence } \\
\text { interval (CI) } 95 \% \text { and/or p-value }\end{array}$ \\
\hline \multirow{6}{*}{2010} & $\begin{array}{c}(52) \\
\text { Germany }\end{array}$ & $\begin{array}{l}\text { Prospective cohort } \\
\qquad \mathrm{n}=9246\end{array}$ & $\begin{array}{l}\text { Interventions preventive of } \\
\text { falls for patients with cognitive } \\
\text { impairment. }\end{array}$ & $\begin{array}{l}\text { Variables associated with statistically significant falls: cognitive } \\
\text { change (2.1; CI 95\%:1.7-2.7); advanced age [67-77 years] }(1.5 ; \text { CI } \\
95 \%: 1.2-1.9) \text {; greater dependency of care }(1.6 \text {; CI } 95 \%: 1.1-2.1) \text {; } \\
\text { altered mobility (2.6; CI 95\%:1.9-3.7) and hospitalization in a } \\
\text { geriatric unit (1.8; CI 95\%: } 1.1-2.9) \text {. Only patients aged }>65 \text { years } \\
\text { were included in the study. }\end{array}$ \\
\hline & $\begin{array}{c}(53) \\
\text { Canadá }\end{array}$ & $\begin{array}{l}\text { Retrospective cohort } \\
\qquad \mathrm{n}=370\end{array}$ & $\begin{array}{l}\text { Amputation at transtibial level } \\
\text { and on the right should be val- } \\
\text { ued at admission. }\end{array}$ & $\begin{array}{l}61 \text { patients suffered falls. Incidence } 16.5 \% \text { (CI } 95 \%: 12.7-20.3) \text {. } \\
\text { Permanence of } 72 \text { days for those who fell and } 40 \text { days for those } \\
\text { who did not fall }(\mathrm{p}<0.001) \text {. Among the } 61 \text { who fell, } 40 \text { fell only } \\
\text { once, and } 21 \text { more than once. There was no difference between } \\
\text { falls and no falls regarding gender, age, number of medications } \\
\text { and comorbidities. Risk factors: fracture etiology as vascular dis- } \\
\text { ease }(2.4 \text {; CI: } 95 \% \text { : } 1.0-5.6) \text {; transtibial }(2.1 ; \text { IC95\%: } 1.0-4.3) \text { and } \\
\text { amputation on the right side }(1.9 ; \text { CI } 95 \%: 1.0-3.4) \text {. }\end{array}$ \\
\hline & $\begin{array}{l}(54) \\
\text { Colômbia }\end{array}$ & $\begin{array}{l}\text { Cross-sectional } \\
\quad \mathrm{n}=14500\end{array}$ & $\begin{array}{l}\text { Surveillance system for moni- } \\
\text { toring the falls. }\end{array}$ & $\begin{array}{l}156 \text { falls. } 60.3 \% \text { in public institution and } 39.7 \% \text { in private. } 60 \% \text { in } \\
\text { men and } 54.7 \% \text { in patients }>60 \text { years. Intrinsic factors: neurologi- } \\
\text { cal, cardiac, respiratory, metabolic and mental alterations }(25.9 \%) \text {, } \\
\text { followed by age }(24.1 \%) \text {. Extrinsic factors: lack of support }(38 \%) \text {, } \\
\text { wet or slippery floor }(35 \%) \text {. }\end{array}$ \\
\hline & $\begin{array}{l}(55) \\
\text { Brazil }\end{array}$ & $\begin{array}{l}\text { Cross-sectional } \\
\mathrm{n}=826 \\
\text { reports of adverse } \\
\quad \text { events }\end{array}$ & $\begin{array}{l}\text { Characterization of falls in the } \\
\text { hospital as a form of investiga- } \\
\text { tion. }\end{array}$ & $\begin{array}{l}0.30 \text { falls per } 1,000 \text { patients-day. } 63.7 \% \text { occcurred at night and } \\
61.7 \% \text { in the first five days after admission. In } 59.2 \% \text { of cases of } \\
\text { falls from bed, the frequency distribution of comorbidities was: in- } \\
\text { fectious and parasitic }(18.2 \%) \text {, nervous system }(18.2 \%) \text {, circulatory } \\
\text { system }(13.7 \%) \text { and digestive }(9.1 \%) \text {. In } 61.3 \% \text { of cases of fall from } \\
\text { height, diagnoses were: cancer }(19.4 \%) \text {, diseases of the genitouri- } \\
\text { nary system }(16.1 \%) \text {, circulatory }(12.9 \%) \text { and respiratory }(12.9 \%) \text {. }\end{array}$ \\
\hline & $\begin{array}{c}(56) \\
\text { Austrália }\end{array}$ & Literature review & $\begin{array}{l}\text { General review on risk factors } \\
\text { for falls. }\end{array}$ & $\begin{array}{l}\text { Most consistent risk factors: history of falls, muscle weakness, agi- } \\
\text { tation and confusion, urinary incontinence or increased frequency, } \\
\text { use of sedatives and postural hypotension. }\end{array}$ \\
\hline & $\begin{array}{l}(57) \\
\text { EUA }\end{array}$ & Literature review & $\begin{array}{l}\text { Identification of risk factors for } \\
\text { falls in the elderly with cancer. }\end{array}$ & $\begin{array}{l}\text { Radiotherapy can contribute to fatigue, anxiety, depression and } \\
\text { lethargy. Surgical procedures, alone or in combination with } \\
\text { chemotherapy or radiotherapy showed physical impairment. } \\
\text { Chemotherapy causes neurotoxicity: unsteady gait, confusion, } \\
\text { peripheral neuropathy, sensory and deep tendon reflexes loss, } \\
\text { postural hypotension, abnormal gait, paresthesia, anemia and } \\
\text { cognitive impairment. }\end{array}$ \\
\hline \multirow{5}{*}{2011} & $\begin{array}{l}(58) \\
\text { EUA }\end{array}$ & $\begin{array}{l}\text { Case-control } \\
\text { Cases }=10 / \\
\text { Controls }=25\end{array}$ & $\begin{array}{l}\text { Interventions for patients who } \\
\text { had documented fall in hospi- } \\
\text { talization }\end{array}$ & $\begin{array}{l}\text { Mean hospital stay was of } 6.5 \text { days }(\mathrm{SD}= \pm 3.5) \text {. Length of hospital } \\
\text { stay }(\mathrm{p}<0.001) \text {. The average daily steps for the sample was } 623.0 \\
\text { (interquartile range } 63.5-843.0) \text {. All patients fell during the night; } \\
60 \% \text { of falls occurred during the bath. }\end{array}$ \\
\hline & $\begin{array}{l}(59) \\
\text { EUA }\end{array}$ & $\begin{array}{l}\text { Prospective cohort } \\
\qquad \mathrm{n}=7851\end{array}$ & $\begin{array}{l}\text { Identification of variables as- } \\
\text { sociated with falls. }\end{array}$ & $\begin{array}{l}\text { The variables with } \mathrm{p}<0.05 \text { were: senility and organic mental disor- } \\
\text { ders, anemia, depression, medical procedures, CT scans, radiation } \\
\text { therapy, anticonvulsant, diuretic, laxative, anti-inflammatory drugs, } \\
\text { antipsychotics, antidepressants, barbiturates and benzodiazepines. }\end{array}$ \\
\hline & $\begin{array}{l}(60) \\
\text { United } \\
\text { Kingdom }\end{array}$ & Systematic review & $\begin{array}{l}\text { Evidence on risk factors for } \\
\text { falls in geriatric rehabilitation } \\
\text { hospitals. }\end{array}$ & $\begin{array}{l}\text { Significant risk factors: carpet, dizziness, lower limb amputation, } \\
\text { confusion, cognitive impairment, CVA, sleep disorders, medica- } \\
\text { tions (anticonvulsants, tranquilizers, antihypertensives), age 71-80 } \\
\text { years, prior history of fall and help for transfer. }\end{array}$ \\
\hline & $\begin{array}{l}(61) \\
\text { EUA }\end{array}$ & Systematic review & $\begin{array}{l}\text { Interventions to decrease falls in } \\
\text { the hospital setting. }\end{array}$ & $\begin{array}{l}\text { Extrinsic risk factors: environmental (bed height, slippery/ } \\
\text { wet floor, shoes and/or inappropriate floor with poor lighting } \\
\text { conditions). Intrinsic risk factors: mental and / or sensory (vision } \\
\text { problems, dizziness and hearing) impairments, mobility difficulties } \\
\text { and use of psychotropic medications. }\end{array}$ \\
\hline & $\begin{array}{l}(62) \\
\text { EUA }\end{array}$ & Literature review & $\begin{array}{l}\text { Review of instruments for as- } \\
\text { sessing risk of falls. }\end{array}$ & $\begin{array}{l}\text { Hospital features: bed size, organizational structure, urban/rural } \\
\text { location, level of use of personnel, nursing care and computerized } \\
\text { systems. Unit features: unit type, length of stay and bed height, } \\
\text { response time to the call of lights, adoption of protocols and safety } \\
\text { culture. Individual characteristics: Comorbidities, age, sex, sleep } \\
\text { disturbances, fatigue, among others. }\end{array}$ \\
\hline
\end{tabular}

Continued... 


\begin{tabular}{|c|c|c|c|c|}
\hline Year & $\begin{array}{l}\text { (Study) } \\
\text { Country }\end{array}$ & $\begin{array}{l}\text { Design/ } \\
\text { Number of patients }\end{array}$ & Interventions & $\begin{array}{c}\text { Risk factor/Relative risk (RR) or Odds ratio (OR)/Confidence } \\
\text { interval (CI) } 95 \% \text { and/or p-value }\end{array}$ \\
\hline \multirow{12}{*}{2012} & $\begin{array}{c}(63) \\
\text { Austrália }\end{array}$ & $\begin{array}{l}\text { Prospective cohort } \\
\qquad n=483\end{array}$ & $\begin{array}{l}\text { Determining the predictive value } \\
\text { of item } 2 \text { of the self-report ques- } \\
\text { tionnaire about bathroom use. }\end{array}$ & $\begin{array}{l}\text { CVA: (CI 95\%: } 2.2-3.0 ; \mathrm{p}<0.001) \text {; dementia: (CI 95\%: 1.2-11; } \\
\text { p<0.001); history of falls: (CI 95\%: 1.3-5.6; }<<0.001) \text {. }\end{array}$ \\
\hline & $\begin{array}{l}(64) \\
\text { EUA }\end{array}$ & $\begin{array}{l}\text { Cross-sectional } \\
\quad \mathrm{n}=1063\end{array}$ & $\begin{array}{l}\text { Monitoring and reduction in } \\
\text { time for assistance after using } \\
\text { the call light. }\end{array}$ & $\begin{array}{l}4.08 \text { falls } / 1000 \text { patients-day, standard deviation }(\mathrm{SD}) \pm 3.06 \text {. Units } \\
\text { with the highest rate of use of the call light and quick response } \\
\text { had fewer falls. The largest number of working hours of nurses is } \\
\text { associated with lower rates of falls. }\end{array}$ \\
\hline & $\begin{array}{l}(65) \\
\text { EUA }\end{array}$ & $\begin{array}{l}\text { Cross-sectional } \\
\quad \mathrm{n}=1732\end{array}$ & $\begin{array}{l}\text { Implementation of protocols in } \\
\text { the prevention of falls. }\end{array}$ & $\begin{array}{l}\text { Patients with CVA, spinal cord injury and other neurological } \\
\text { problems are at greater risk of falling. Quality staff and educa- } \\
\text { tion of those involved in the use of best practices can reduce the } \\
\text { incidence of falls. }\end{array}$ \\
\hline & $\begin{array}{l}(66) \\
\text { Japan }\end{array}$ & $\begin{array}{l}\text { Prospective cohort } \\
\qquad \mathrm{n}=2973\end{array}$ & $\begin{array}{l}\text { Specific interventions to prevent } \\
\text { falls and its consequences. }\end{array}$ & 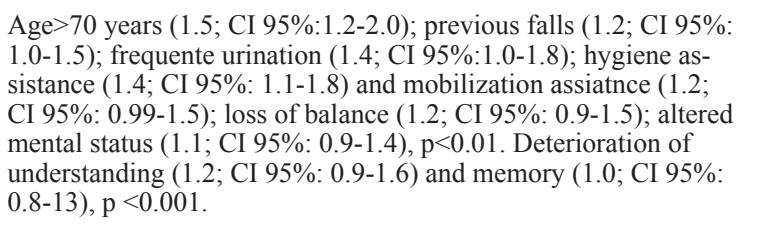 \\
\hline & $\begin{array}{l}(67) \\
\text { Bósnia }\end{array}$ & $\begin{array}{l}\text { Cross-sectional } \\
\quad \mathrm{n}=1809\end{array}$ & $\begin{array}{l}\text { Characterization of the falls as a } \\
\text { form of investigation. }\end{array}$ & $\begin{array}{l}\mathrm{n}=61(3.3 \%) \text { patients with CVA fell. Among these, } \mathrm{n}=42 \\
(68.86 \%) \text { had disorientation; } \mathrm{n}=47(77.05 \%) \text { aphasia; } \mathrm{n}=38 \\
(62.29 \%) \text { of falls occurred at night and } \mathrm{n}=44(72 \%) \text { until the fifth } \\
\text { day of hospitalization. }\end{array}$ \\
\hline & $\begin{array}{l}(68) \\
\text { Portugal }\end{array}$ & $\begin{array}{l}\text { Cross-sectional } \\
\text { Admissions (unit of } \\
33 \text { beds) }\end{array}$ & $\begin{array}{l}\text { Characterization of the falls for } \\
\text { planning preventive measures. }\end{array}$ & $\begin{array}{l}\text { Relevant risk factors: confusion, agitation, decreased muscle } \\
\text { strength, gait limitations and collapse. }\end{array}$ \\
\hline & $\begin{array}{c}(69) \\
\text { Austrália }\end{array}$ & $\begin{array}{l}\text { Prospective cohort } \\
\qquad \mathrm{n}=434\end{array}$ & $\begin{array}{l}\text { Construction of a model of } \\
\text { prediction of risk of falls. }\end{array}$ & $\begin{array}{l}\text { Predictors of falls: male gender }(2.32 ; \text { CI } 95 \%: 1.00-4.03) \text {; drug } \\
\text { for the central nervous system }(2.04 \text {; CI } 95 \%: 1.00-3.30) \text {; increased } \\
\text { postural sway }(1.93 \text {; CI } 95 \%: 1.00-3.26) \text {. }\end{array}$ \\
\hline & $\begin{array}{c}(70) \\
\text { Austrália }\end{array}$ & $\begin{array}{l}\text { Coorte retrospectivo } \\
\qquad \mathrm{n}=194\end{array}$ & $\begin{array}{l}\text { Influence of nutritional status } \\
\text { on the physical functioning of } \\
\text { the patient. }\end{array}$ & Factors highlighted in the study: elderly and impaired mobility. \\
\hline & $\begin{array}{l}(71) \\
\text { China }\end{array}$ & $\begin{array}{l}\text { Case-control } \\
\text { Casos } n=165 / \\
\text { Controls } n=165\end{array}$ & $\begin{array}{l}\text { Decrease in use of Zolpidem, } \\
\text { benzodiazepines, narcotics and } \\
\text { antihistamines. }\end{array}$ & $\begin{array}{l}\text { Cancer in elderly patients, first week of hospitalization and medi- } \\
\text { cation use }(24 \mathrm{~h} \text { before the event): benzodiazepines }(2.63 ; \text { CI } 95 \% \text { : } \\
1.55-4.46 ; \mathrm{p}<0.001) \text {; Zolpidem }(2.38 ; \text { IC } 95 \%: 1.04-5.43 ; \mathrm{p}<0.040) \text {; } \\
\text { narcotics }(2.13 ; \text { CI 95\%: } 1.16-3.94 ; \mathrm{p}<0.015) \text { and antihistamine } \\
(3.00 ; \text { CI } 95 \%: 1.19-7.56 ; \mathrm{p}<0.020) \text {. }\end{array}$ \\
\hline & $\begin{array}{l}(72) \\
\text { China }\end{array}$ & $\begin{array}{l}\text { Cross-sectional } \\
\quad \mathrm{n}=725\end{array}$ & $\begin{array}{l}\text { Use of an information system to } \\
\text { identify the risk factors for falls. }\end{array}$ & $\begin{array}{l}\mathrm{n}=72 \text { falls. Risk factors }(\mathrm{p}<0.05) \text { : age over } 65 \text { years; comorbidities; } \\
\text { first weeks of hospitalization; multiple drug use; antipsychotic; } \\
\text { diuretic; high score for risk of fall. }\end{array}$ \\
\hline & $\begin{array}{l}(73) \\
\text { Brazil }\end{array}$ & $\begin{array}{l}\text { Cross-sectional } \\
\qquad n=53\end{array}$ & $\begin{array}{l}\text { Characterization of falls for } \\
\text { planning a prevention program. }\end{array}$ & $\begin{array}{l}\text { The average number of risk factors reported by patients with } \\
\text { falls was } 11(\mathrm{SD} \pm 3) \text {. Impaired physical mobility, acute disease, } \\
\text { impaired balance and diminished mental state appear in } 80 \% \text { of } \\
\text { cases. } 56.6 \% \text { of falls occurred at night. }\end{array}$ \\
\hline & $\begin{array}{l}\text { (74) } \\
\text { Egypt }\end{array}$ & $\begin{array}{l}\text { Cross-sectional } \\
\mathrm{n}=1779\end{array}$ & $\begin{array}{l}\text { Greater care for patients with } \\
\text { certain characteristics. }\end{array}$ & $\begin{array}{l}\text { Age }>60 \text { years, chronic diseases, difficulty in gait because of neuro- } \\
\text { logical changes and by use of devices to assist in gait, urinary } \\
\text { incontinence and nighttime urination, vision problems. }\end{array}$ \\
\hline
\end{tabular}

Chart 2 shows the use of rating scales for risk for falls among adults in the hospital context, more specifically in clinical/surgical inpatient units, in 10 studies (14\%).
The risk factors for falls presented in this review are related to the patient (intrinsic), the hospital environment and the working process of health professionals, especially in nursing (extrinsic). 
Chart 2 - Predictive scales for falls and its risk factors - Porto Alegre, RS, 2012.

\begin{tabular}{|c|c|c|c|c|c|}
\hline Year & $\begin{array}{l}\text { (Study) } \\
\text { Country }\end{array}$ & $\begin{array}{l}\text { Design/ } \\
\text { Outcome }\end{array}$ & Scale(s) & Risk factors & Sample and main results \\
\hline 2004 & $\begin{array}{c}(75) \\
\text { United } \\
\text { Kingdom }\end{array}$ & Literature review & $\begin{array}{l}\text { Morse Fall Scale, } \\
\text { STRATIFY, } \\
\text { Harrogate Assessment, } \\
\text { Assessment for High } \\
\text { Risk to Fall Research } \\
\text { Instrument, Risk } \\
\text { Assessment for Falls } \\
\text { Scale II (RAFS II), } \\
\text { Fall Risk Assessment } \\
\text { Scale for the Elderly } \\
\text { (FRASE) }\end{array}$ & $\begin{array}{l}\text { History of falls; mental, mobil- } \\
\text { ity and sensory abnormalities; } \\
\text { medication use; secondary } \\
\text { diagnosis; difficulty in gait; } \\
\text { urinary abnormalities; deficit } \\
\text { in communication; inappropri- } \\
\text { ate footwear; age; intravenous } \\
\text { therapy; length of stay. }\end{array}$ & $\begin{array}{l}\text { The study shows the risk factors of differ- } \\
\text { ent scales. }\end{array}$ \\
\hline 2006 & $\begin{array}{l}(76) \\
\text { Switzer- } \\
\text { land }\end{array}$ & $\begin{array}{l}\text { Prospective cohort / } \\
\text { Queda(s) }\end{array}$ & Morse Fall Scale & \multirow{4}{*}{$\begin{array}{l}\text { History of falls, presence of sec- } \\
\text { ondary diagnosis, need for assis- } \\
\text { tance in ambulation or transfer, } \\
\text { use of intravenous medication } \\
\text { and altered mental status. }\end{array}$} & $\begin{array}{l}\mathrm{n}=386 \text { patients. } 12.2 \% \text { of patients had } \\
\text { falls. The best cutoff point was } 55 \text { points } \\
\text { with sensitivity of } 74.5 \% \text {, specificity of } \\
65.8 \% \text {, negative predictive value } 94.9 \% \\
\text { and accuracy of } 66.8 \% \text {. The positive } \\
\text { predictive value ranged from } 12 \text { to } 24 \% \text { in } \\
\text { different cutoffs. }\end{array}$ \\
\hline 2007 & $\begin{array}{l}(77) \\
\text { Switzer- } \\
\text { land }\end{array}$ & $\begin{array}{l}\text { Prospective cohort / } \\
\text { Fall(s) }\end{array}$ & Morse Fall Scale & & $\begin{array}{l}\mathrm{n}=275 \text { patients. During the four months } \\
\text { of study } 41(14.9 \%) \text { patients fell at least } \\
\text { once. The score of } 55 \text { had } 80 \% \text { of sensitiv- } \\
\text { ity (CI } 95 \%: 66-90), 59 \% \text { of specificity (CI } \\
95 \%: 53-65) \text {, positive and negative predic- } \\
\text { tive values of } 26 \text { and } 95 \% \text {, respectively, } \\
\text { considering this is the most appropriate } \\
\text { cutoff. }\end{array}$ \\
\hline 2009 & $\begin{array}{l}(78) \\
\text { EUA }\end{array}$ & Qualitative & Morse Fall Scale & & $\begin{array}{l}\text { The nurses }(\mathrm{n}=42) \text { reported using the } \\
\text { Morse Fall Scale, but considered it } \\
\text { incomplete. }\end{array}$ \\
\hline \multirow[t]{2}{*}{2010} & $\begin{array}{l}(79) \\
\text { EUA }\end{array}$ & $\begin{array}{l}\text { Randomized } \\
\text { clinical trial/Fall(s) }\end{array}$ & Morse Fall Scale & & $\begin{array}{l}\mathrm{n}=5104 \text { patients in the control group and } \\
\mathrm{n}=5,160 \text { in the intervention group. There } \\
\text { was difference in the adjusted rate of falls } \\
/ 1,000 \text { patients-day in the control group } \\
(4.18) \text { and the intervention group }(3.15), \\
\mathrm{p}=0.04 \text {. The result in the intervention } \\
\text { group (Fall prevention kit) in patients } \\
\text { older than } 65 \text { years was significantly bet- } \\
\text { ter than in young people }(\mathrm{p}=0.02) \text {. }\end{array}$ \\
\hline & $\begin{array}{c}(80) \\
\text { Austrália }\end{array}$ & $\begin{array}{l}\text { Prospective } \\
\text { cohort /Fall(s) }\end{array}$ & STRATIFY & $\begin{array}{l}\text { History of falls; level of } \\
\text { consciousness (confusion, } \\
\text { disorientation and agitation); } \\
\text { visual changes; frequency of } \\
\text { trips to the bathroom; transfer } \\
\text { and mobility. }\end{array}$ & $\begin{array}{l}n=788 \text { patients. Incidence of falls }=9.2 \% \text {. } \\
\text { Sensitivity of } 50.82 \% \text {, specificity of } \\
50.61 \% \text {, positive predictive value of } \\
50.18 \% \text { and negative predictive value of } \\
50.97 \% \text {. }\end{array}$ \\
\hline 2011 & $\begin{array}{c}(81) \\
\text { Turkey }\end{array}$ & $\begin{array}{l}\text { Prospective } \\
\text { cohort /Fall(s) }\end{array}$ & Downton & $\begin{array}{l}\text { History of falls, medication } \\
\text { administration, sensory deficit, } \\
\text { altered mental status and am- } \\
\text { bulation }\end{array}$ & $\begin{array}{l}\mathrm{n}=99 \text { patients. Incidence of } \\
\text { falls }=6.3 / 1,000 \text { patients-day (CI } 95 \% \text { : } \\
3.7-10.1) . \text { The scale score at admission } \\
\text { was significantly lower in patients who } \\
\text { did not fall in relation to the group that } \\
\text { fell }(\mathrm{p}<0.05) .50 \% \text { of falls occurred while } \\
\text { walking and the second in frequency was } \\
\text { during transfer. }\end{array}$ \\
\hline \multirow[b]{2}{*}{2011} & $\begin{array}{l}(82) \\
\text { EUA }\end{array}$ & $\begin{array}{l}\text { Cross-sectional/ } \\
\text { Fall(s) }\end{array}$ & Johns Hopkins & $\begin{array}{l}\text { Cognitive status, age, history of } \\
\text { falls, elimination, medications, } \\
\text { mobility and assistive devices. }\end{array}$ & $\begin{array}{l}65 \%(n=7900) \text { of more than } 12000 \text { studied } \\
\text { patients were at risk of falls in the period } \\
\text { between } 2008 \text { and } 2011 \text { and the total num- } \\
\text { ber of falls decreased by } 16.6 \% \text {. }\end{array}$ \\
\hline & $\begin{array}{l}(83) \\
\text { Singapore }\end{array}$ & $\begin{array}{l}\text { Randomized } \\
\text { clinical trial/Fall(s) }\end{array}$ & $\begin{array}{l}\text { Hendrich II Fall Risk } \\
\text { Model }\end{array}$ & \multirow{2}{*}{$\begin{array}{l}\text { Confusion/disorientation/ } \\
\text { agitation/dizziness; symptom- } \\
\text { atic depression; amendment of } \\
\text { eliminations; gender (male); use } \\
\text { of benzodiazepines and antiepi- } \\
\text { leptics and review by the timed } \\
\text { up and go test. }\end{array}$} & $\begin{array}{l}\mathrm{n}=912 \text { patients in the control group } \\
\text { and } \mathrm{n}=910 \text { in the intervention group. } \\
\text { Sensitivity }(70 \%, 95 \% \text { CI: } 57.5-80.1) \text { and } \\
\text { specificity }(61.5 \%, 95 \% \text { CI: } 60.2-62.8) \text {. } \\
\text { The area under the Receiver Operating } \\
\text { Characteristic (ROC) curve was } 73 \% \text {. }\end{array}$ \\
\hline 2012 & $\begin{array}{l}(84) \\
\text { EUA }\end{array}$ & $\begin{array}{l}\text { Randomized } \\
\text { clinical trial/Fall(s) }\end{array}$ & $\begin{array}{l}\text { Hendrich II Fall Risk } \\
\text { Model }\end{array}$ & & $\begin{array}{l}n=682 \text { hospitalizations in the control group, } \\
n=775 \text { and } n=838 \text { in the intervention } \\
\text { groups. There was no statistically signifi- } \\
\text { cant variation in the scores of the risk scale } \\
\text { and in the rate of falls after the implemen- } \\
\text { tation of a protocol for preventing falls. }\end{array}$ \\
\hline
\end{tabular}




\section{DISCUSSION}

Considering the number of studies on risk factors for falls included in this integrative review, among which 23 were published in the USA (32.3\%), followed by Australia with eight studies (11.2\%) and the United Kingdom with seven (9.8\%), it is noteworthy that the subject of patient safety had a great impact in the late 1990s in the U.S., from the publication of the report called Toerrishuman: building a safer health system by the Institute of Medicine. This report estimated that between 44,000 and 98,000 Americans die each year due to preventable errors in healthcare ${ }^{(85)}$. This concern also gained ground in countries like Australia, UK and Latin America (Brazil, Colombia) ${ }^{(85)}$.

Among the 18 countries of studies, Brazil is in eigth place in terms of publication, with three papers (4.2\%).

In the early twentieth century came a conducive environment for the incorporation of actions for safety in health care and, consequently, for the development of scientific research on this issue in Brazil. One of these actions was the creation of the National Health Surveillance Agency (ANVISA), in 1999, by the government of Fernando Henrique Cardoso, to ensure the health safety of products and services ${ }^{(86-87)}$.

In October 2004, the Ministry of Health launched the National Alliance for Patient Safety (Aliança Nacional para a Segurança do Paciente), with the aim of spreading knowledge and solutions found to improve care processes involved in patient safety ${ }^{(88)}$. In this context, by initiative of the Pan American Health Organization, was established the Brazilian Network of Nursing and Patient Safety - REBRAENSP, in May 2008. This was a strategy adopted by a group of nurses for the articulation and cooperation between institutions of health and education, aiming at strengthening the safety and quality care ${ }^{(87)}$.

As a result of the global movements related to this problem, scientific studies have been carried out in order to identify and understand the errors and adverse events, take corrective and proactive measures, analyze systemic failures and its causal factors, as well as to develop strategies that ensure a safe practice ${ }^{(89)}$.

The number of publications progressively increases, showing the increasingly imminent need of approaching issues related to the knowledge and safety of risk factors for falls in the hospital setting. The term called patient safety is defined as the reduction to a minimum acceptable level/degree of unnecessary risk of harm during the health assistance ${ }^{(90)}$.

The development of studies related to the risk of unnecessary harm, in particular to falls in inpatient and/or surgical units, is distributed in 23 cross-sectional studies $(32.3 \%)$, highlighting the number of 19 cohort studies (26.7\%), nine case-control studies (12.7\%) and five randomized clinical trials (7\%). It is observed that studies of higher level of evidence are developed in smaller numbers, which demonstrates the need for researchers to carry out robust jobs that best characterize predictors of falls.

Risk factors related to patients represent the majority of predictors of falls identified in the reviewed studies, in which several terms used to assess the level of consciousness of patients were identified, such as disorientation, confusion, dementia, organic mental disorder, cognitive impairment, delirium and even agitation.

Another risk factor that is approached in different ways includes assessing the mobility of patients that is described as changed, with loss of balance, difficulty in gait and sensory disabilities ${ }^{(16,38,66)}$.

It was found that reports of the identification of the sensory and mobility of patients, especially at the time of the fall, are uncommon. One of the possible reasons is the lack of assessment records of patients on the outcome or, when these are available, are also often inaccurate ${ }^{(91)}$. The different terms used may indicate the complexity of the evaluation of these aspects.

In this sense, the construction of conceptual and operational definitions for risk factors could help to understand the different terms used to express the same situation.

Regarding the use of drugs, those with potential depression of the central nervous system are related to falls, such as benzodiazepines ${ }^{(26,30,32,34,37,43,49,59,60,71)}$, antipsychotics $^{(26,33,38,44,49,56,59,72)}$, antidepressants ${ }^{(37,43,59)}$, narcotics/opiate ${ }^{(33-34,71)}$, barbiturate ${ }^{(14,16,27,32,37,47-48)}$, antihistamines $(31,36,71)$, anticonvulsants ${ }^{(31,36,44,59,60)}$ and sedatives ${ }^{(20,27,37)}$ in general. Medicines that may cause hypotension are also associated with risk of falls (antihypertensives) $)^{(16,26,35,49,60)}$, in addition to diuretics $^{(16,26,36-37,59,74)}$. Laxatives were mentioned in a few studies $^{(37,72,59)}$. However, the antidiabetics that have excelled in only one case-control study ${ }^{(31)}$ and another crosssectional ${ }^{(49)}$, and the antiarrhythmics ${ }^{(26,43)}$ and anticoagulants ${ }^{(44)}$, that were mentioned in this integrative review only in literature reviews, do not seem to show strong enough evidence to be associated with the outcome.

These evidences reinforce the need for professionals knowing the risk factors for falls, and the criteria to identify and evaluate them in patients, because only few instruments checked for risk assessment of falls were tested in different scenarios, such as the Morse Fall Scale ${ }^{(92-93)}$, the St Thomas Risk Assessment Tool in Falling Elderly Inpatients ${ }^{(94-95)}$ (STRATIFY) and the Heindrich II Fall Risk Model(96), instruments that vary in terms of sensitivity and specificity ${ }^{(94)}$. There is also the Dowton's Risk of Falls Scale ${ }^{(97)}$, which groups only intrinsic risk factors. This scale has not shown to be accurate in the prediction of falls either ${ }^{(97)}$, or has been used in an adapted form with the inclusion of some risk factors of the nursing diagnosis Risk of falls among its components $^{(98)}$. Other scales such as the Johns Hopkins ${ }^{(83)}$, the
Risk factors for falls in hospitalized adult patients: an integrative review

Severo IM, Almeida MA, Kuchenbecker R, Vieira DFVB, Weschenfelder ME, Pinto LRC, Klein C, Siqueira APO, Panato BP 
Harrogate Assessment, the RAFS II and the FRASE ${ }^{(84)}$ were also mentioned in this review, but did not show validation tests in different contexts.

This corroborates that extrinsic, environmental factors or related to the work-process, together or not with intrinsic risk factors, are crucial for risk identification, as mentioned in studies that associate infection risks to factors related to work and professional qualification ${ }^{(99)}$. From the view of health problems related to hospital infections such as the prevalence of infections and multidrug-resistant organisms, there is published evidence ${ }^{(99)}$ establishing associations between such events and the staff-patient relationship.

However, from the analysis of risk factors in the hospital environment, a gap was identified in knowledge by producing a small number of research related to staff-patient questions and how it is linked to the risk of patients suffering falls. And even intrinsic aspects such as fear of falling, were not mentioned in the different types of study of this integrative review, despite having shown to be important risk factors ${ }^{(100)}$.

\section{REFERENCES}

1. Evans D, Hodgkinson B, Lambert L, Wood J. Falls risk factors in the hospital setting: a systematic review. Int J Nurs Pract. 2001;7(1):38-45.

2. Abreu C, Mendes A, Monteiro J, Santos FR. Falls in hospital settings: a longitudinal study. Rev Lat Am Enferm [Internet]. 2012 [cited 2013 June 03];20(3). Available from: http://www. scielo.br/pdf/rlae/v20n3/pt_a23v20n3.pdf

3. World Health Organization (WHO). WHO Global Report on Falls Prevention in Older Age [Internet]. Geneva; 2007 [cited 2013 June 03]. Available from: http://www.who.int/ageing/ publications/Falls_prevention7March.pdf

4. National Patient Safety Agency. Slips trips and falls in hospital [Internet]. London; 2007 [cited 2013 Jan 01]. Available from: http://www.nrls.npsa.nhs.uk/EasySiteWeb/getresource. axd?AssetID=61390\&

5. National Patient Safety Agency. Slips trips and falls data update NPSA [Internet]. London; 2010 [cited 2013 Jan 02]. Available from: http://www.nrls.npsa.nhs.uk/EasySiteWeb/getresource.axd?AssetID=74565\&

6. Salgado RI, Stephen RL, Frederick E, Janji N, Rahman A. Predictors of falling in elderly hospital patients. Arch Gerontol Geriatr. 2004;(38):213-9.

\section{CONCLUSION}

This integrative review identified risk factors for falls of hospitalized adult patients, especially in inpatient clinical and/or surgical units. The intrinsic risk factors are important in predicting the risk of falls, as demonstrated in the studies. However, factors related to work processes, such as the staff-patient relationship, are also key. From the studies analysis it was found a gap on risk factors, especially those related to the work process as an additive outcome.

Regarding the diversity of studies presented in this integrative review, we can not fail to mention that the risk factors, according to the methodological rigor of each study, may have different weights in the prediction of the event.

With this work, we hope to have contributed to the expansion of knowledge about issues of patient safety and clinical practice of health professionals, especially in nursing, helping with the non-occurrence of falls, which despite being a preventable event can cause death.

7. Gawryszewski VP, Monteiro RA, Bandeira de Sá NN, Mascarenhas MDM, Silva MMA, Bernal R, et al. Acidentes e violências no Brasil: um panorama atual das mortes, internações hospitalares e atendimentos em serviços de urgência. In: Brasil. Ministério da Saúde; Secretaria de Vigilância em Saúde. Saúde Brasil 2009. Brasília; 2010. p.137-73.

8. Siqueira VS, Facchini LA, Silveira DS, Piccini RX, Tomasi E, Thumé $E$, et al. Prevalence of falls in elderly in Brazil: a countrywide analysis. Cad Saúde Pública. 2011;27(9):1819-26.

9. Marin HF, Bourie P, Safran C. Desenvolvimento de um sistema de alerta para prevenção de quedas em pacientes hospitalizados. Re Lat Am Enferm [Internet]. 2000 [citado 2013 jan. 01];8(3):27-32. Disponível em: http://www.scielo.br/pdf/ rlae/v8n3/12396.pdf

10. Stevens JA, Corso OS, Finkelstein EA, Miller TR. The costs of fatal and non-fatal falls among older adults. Inj Prev. 2006;12(5):290-5.

11. Brasil. Ministério da Saúde. Quedas em idosos [Internet] Brasília; 2009 [citado 2013 fev. 03]. Disponível em: http://portal.saude.gov.br/portal/saude/visualizar_texto. cfm?idtxt=33674\&janela=1

12. Cooper HM. Integrating research: a guide for literature reviews. 2nd ed. London: Sage; 1989.

13. Morse JM, Morse RM, Tylko SJ. Development of a scale to identify the fall-prone patient. Can J Aging. 1989;8(4):366-377. 
14. Chu LW, Pei CK, Chiu A, Liu K, Chu MM, Wong S, et al. Risk factors for falls in hospitalized older medical patients. J Gerontol A Biol Sci Med Sci. 1999;54(1):M38-43.

15. Halfon P, Eggli Y, Van Melle G, Vagnair A. Risk of falls for hospitalized patients: a predictive model based on routinely available data. J Clin Epidemiol. 2001;54(12):1258-66.

16. Rocha FL, Marziale MHP. Prevenção de quedas em pacientes: cuidado de enfermagem. Acta Paul Enferm. 2001;14(1):62-71.

17. Aizen E, Dranker N, Swartzman R, Michalak R. Risk factors and characteristics of falls resulting in hip fracture in the elderly. Isr Med Assoc J. 2003;5(5):333-6.

18. Donoghue J, Graham J, Gibbs J, Mitten-Lewis S. Who, where and why: situational and environmental factors contributing to patient falls in the hospital setting. Aust Health Rev [Internet]. 2003 [cited 2013 Mar 12];26(3):79-87. Available from: http://www.publish.csiro.au/?act=view_file\&file_ id=AH030079.pdf

19. Salgado RI, Lord SR, Ehrlich F, Janji N, Rahman A. Predictors of falling in elderly hospital patients. Arch Gerontol Geriatr. 2004;38(3):213-219.

20. Currie LM, Mellino LV, Cimino JJ, Bakken S. Development and representation of a fall-injury risk assessment instrument in a clinical information system. Stud Health Technol Inform. 2004;107(Pt 1):721-5.

21. Browne JA, Covington BG, Davila Y. Using information technology to assist in redesign of a fall prevention program. J Nurs Care Qual. 2004;19(3):218-25.

22. Hitcho EB, Krauss MJ, Birge S, Claiborne Dunagan W, Fischer I, Johnson S, et al. Characteristics and circumstances of falls in a hospital setting: a prospective analysis. J Gen Intern Med [Internet]. 2004 [cited 2013 Mar 13];19(7):732-9. Available from: http://www.ncbi.nlm.nih.gov/pmc/articles/ PMC1492485/pdf/jgi_30387.pdf

23. McLean DE. Medical complications experienced by a cohort of stroke survivors during inpatient, tertiary-level stroke rehabilitation. Arch Phys Med Rehabil. 2004;85(3):466-9.

24. Pulcins I, Wan E. In-hospital hip fractures in Canada: using information to improve patient safety. Healthc $Q$. 2004; $7(4): 25-27$.

25. Kerzman $\mathrm{H}$, Chetrit A, Brin L, Toren O. Characteristics of falls in hospitalized patients. J Adv Nurs. 2004;47(2):223-9.

26. Haynes N. Prevention of falls among older patients in the hospital environment. Br J Nurs. 2004;13(15):896-901.
27. Oliver D, Daly F, Martin FC, et al. Risk factors and risk assessment tools for falls in hospital in-patients: a systematic review. Age Ageing [Internet]. 2004 [cited 2012 Nov 08];33(2):122-30. Available from: http://ageing.oxfordjournals.org/content/33/2/122.full.pdf+html

28. Vassallo M, Vignaraja R, Sharma JC, Hallam H, Binns K, Briggs $\mathrm{R}$, et al. The effect of changing practice on fall prevention in a rehabilitative hospital: the Hospital Injury Prevention Study. J Am Geriatr Soc. 2004;52(3):335-9.

29. Haines TP, Bennell KL, Osborne RH, Hill KD. Effectiveness of targeted falls prevention programme in sub acute hospital setting: randomised controlled trial [images]. BMJ. 2004;328(7441):676.

30. Mecocci P, von Strauss E, Cherubini A, Ercolani S, Mariani E, Senin $U$, et al. Cognitive impairment is the major risk factor for development of geriatric syndromes during hospitalization: results from the GIFA study. Dement Geriatr Cogn Disord. $2005 ; 20(4): 262-9$.

31. Walker PC, Alrawi A, Mitchell JF, Regal RE, Khanderia U. Medication use as a risk factor for falls among hospitalized elderly patients. Am J Health Syst Pharm. 2005;62(23):2495-9.

32. Vassallo M, Vignaraja R, Sharma J, Briggs R, Allen S. Tranquillizer use as a risk factor for falls in hospital patients. Int J Clin Pract. 2006;60(5):549-52.

33. Schwendimann R, Bühler H, De Geest S, Milisen K. Falls and consequent injuries in hospitalized patients: effects of an interdisciplinary falls prevention program [images]. BMC Health Serv Res [Internet]. 2006 [cited 2013 Mar 12];6:69. Available from: http://www.ncbi.nlm.nih.gov/pmc/articles/ PMC1534028/

34. Pauley T, Devlin M, Heslin K. Falls sustained during inpatient rehabilitation after lower limb amputation: prevalence and predictors. Am J Phys Med Rehabil. 2006;85(6):521-32.

35. Aizen E, Shugaev I, Lenger R. Risk factors and characteristics of falls during inpatient rehabilitation of elderly patients. Arch Gerontol Geriatr. 2007;44(1):1-12.

36. Amador LF, Loera JA. Preventing postoperative falls in the older adult. J Am Coll Surg. 2007;204(3):447-53.

37. Maclntosh G, Joy J. Assessing falls in older people. Nurs Older People. 2007;19(7):33-6; quiz 37.

38. Schwendimann R, Bühler H, De Geest S, Milisen K. Characteristics of hospital inpatient falls across clinical departments. Gerontology. 2008;54(6):342-8.

39. Kressig RW, Herrmann FR, Grandjean R, Michel JP, Beauchet O. Gait variability while dual-tasking: fall predictor in older inpatients? Aging Clin Exp Res. 2008;20(2):123-30. 
40. Salameh F, Cassuto N, Oliven A. A simplified fall-risk assessment tool for patients hospitalized in medical wards. Isr Med Assoc J. 2008;10(2):125-9.

41. Lee JE, Stokic DS. Risk factors for falls during inpatient rehabilitation. Am J Phys Med Rehabil. 2008;87(5):341-50.

42. Tzeng HM, Yin CY. Heights of occupied patient beds: a possible risk factor for inpatient falls. J Clin Nurs. 2008;17(11):1503-9.

43. Bulat $\mathrm{T}$, Castle SC, Rutledge M, Quigley P. Clinical practice algorithms: medication management to reduce fall risk in the elderly - Part 3, benzodiazepines, cardiovascular agents, and antidepressants. J Am Acad Nurse Pract. 2008;20(2):55-62.

44. Bulat $\mathrm{T}$, Castle SC, Rutledge M, Quigley P. Clinical practice algorithms: medication management to reduce fall risk in the elderly - Part 4, anticoagulants, anticonvulsants, anticholinergics/bladder relaxants, and antipsychotics. J Am Acad Nurse Pract. 2008;20(4):181-90.

45. Lakatos BE, Capasso V, Mitchell MT, Kilroy SM, Lussier-Cushing $M$, Sumner $L$, et al. Falls in the general hospital: association with delirium, advanced age, and specific surgical procedures. Psychosomatics. 2009;50(3):218-26.

46. Tzeng HM, Yin CY. Perspectives of recently discharged patients on hospital fall-prevention programs. J Nurs Care Qual. 2009;24(1):42-9.

47. Chen YC, Chien SF, Chen LK. Risk factors associated with falls among Chinese hospital inpatients in Taiwan. Arch Gerontol Geriatr. 2009;48(2):132-6.

48. Milutinović D, Martinov-Cvejin M, Simić S. Patients' falls and injuries during hospitalization as quality indicators of work in hospitals. Med Pregl [Internet]. 2009 [cited 2012 Nov 10];62(5-6):249-57. Available from: http://www.doiserbia. nb.rs/img/doi/0025-8105/2009/0025-81050906249M.pdf

49. Tsur A, Segal Z. Falls in stroke patients: risk factors and risk management. Isr Med Assoc J. 2010;12(4):216-9.

50. Sada K, Uchiyama J, Ohnishi T, Ninomiya I, Masino Y. Effects of clear visual input and change in standing sequence on standing sway related to falls during night toilet use. Int J Older People Nurs. 2010;5(1):34-40.

51. Schmid AA, Wells CK, Concato J, Dallas MI, Lo AC, Nadeau SE, et al. Prevalence, predictors, and outcomes of poststroke falls in acute hospital setting. J Rehabil Res Dev [Internet]. 2010 [cited 2012 Nov 10];47(6):553-62. Available from: http:// www.rehab.research.va.gov/jour/10/476/pdf/schmid.pdf

52. Härlein J, Halfens RJ, Dassen T, Lahmann NA. Falls in older hospital inpatients and the effect of cognitive impairment: a secondary analysis of prevalence studies. J Clin Nurs. 2011;20(1-2):175-83.
53. Yu JC, Lam K, Nettel-Aguirre A, Donald M, Dukelow S. Incidence and risk factors of falling in the postoperative lower limb amputee while on the surgical ward. PM R. 2010;2(10):926-34.

54. López MEV. Prevalencia de caídas en pacientes hospitalizados en dos instituciones de salud de Pereira. Cultura Cuidado Enferm [Internet]. 2010 [cited 2013 Mar 11];7(1):1623. Disponible en: http://dialnet.unirioja.es/servlet/ articulo?codigo $=3716291$

55. Paiva MCMS, Paiva SAR, Berti HW, Campana AO. Characterization of patient falls according to the notification in adverse event reports. Rev Esc Enferm USP [Internet]. 2010 [cited 2013 Mar 12];44(1):134-18. Available from: http:// www.scielo.br/pdf/reeusp/v44n1/en_a19v44n1.pdf

56. Oliver D, Healey F, Haines TP. Preventing falls and fall-related injuries in hospitals. Clin Geriatr Med. 2010;26(4):645-92.

57. Allan-Gibbs R. Falls and hospitalized patients with cancer: a review of the literature. Clin J Oncol Nurs. 2010;14(6):784-92.

58. Fisher SR, Galloway RV, Kuo YF, Graham JE, Ottenbacher $\mathrm{KJ}$, Ostir GV, et al. Pilot study examining the association between ambulatory activity and falls among hospitalized older adults. Arch Phys Med Rehabil [Internet]. 2011 [cited 2013 Mar 11];92(12):2090-2. Available from: http://www. ncbi.nlm.nih.gov/pmc/articles/PMC3229660/

59. Titler MG, Shever LL, Kanak MF, Picone DM, Qin R. Factors associated with falls during hospitalization in an older adult population. Res Theory Nurs Pract. 2011;25(2):127-48.

60. Vieira ER, Freund-Heritage R, Costa BR. Risk factors for geriatric patient falls in rehabilitation hospital settings: a systematic review. Clin Rehabil. 2011;25(9):788-99.

61. Choi YS, Lawler E, Boenecke CA, Ponatoski ER, Zimring CM. Developing a multi-systemic fall prevention model, incorporating the physical environment, the care process and technology: a systematic review. J Adv Nurs. 2011;67(12):2501-24.

62. Tzeng HM. Using multiple data sources to answer patient safety-related research questions in hospital inpatient settings: a discursive paper using inpatient falls as an example. J Clin Nurs. 2011;20(23-24):3276-84.

63. Ko A, Van NH, Chan L, Shen Q, Ding XM, Chan DL, et al. Developing a self-reported tool on fall risk based on toileting responses on in-hospital falls. Geriatr Nurs. 2012;33(1):9-16.

64. Tzeng HM, Titler MG, Ronis DL, Yin CY. The contribution of staff call light response time to fall and injurious fall rates: an exploratory study in four US hospitals using archived hospital data. BMC Health Serv Res [Internet]. 2012 [cited 2013 Mar 13];12:84. Available from: http://www.biomedcentral. com/content/pdf/1472-6963-12-84.pdf 
65. Forrest G, Huss S, Patel V, Jeffries J, Myers D, Barber C, et al. Falls on an inpatient rehabilitation unit: risk assessment and prevention. Rehabil Nurs. 2012;37(2):56-61.

66. Tanaka B, Sakuma M, Ohtani M, Toshiro J, Matsumura T, Morimoto T. Incidence and risk factors of hospital falls on long-term care wards in Japan. J Eval Clin Pract. 2012;18(3):572-7.

67. Sinanović $O$, Raicevic B, Brkic M, Hajdarbegovic E, Zukić $S$, Kojić $B$, et al. Falls in hospitalized acute stroke patients. Med Arh. 2012;66(1):33-4.

68. Abreu C, Mendes A, Monteiro J, Santos FR. Falls in hospital settings: a longitudinal study. Rev Lat Am Enferm. 2012;20(3):597-603.

69. Sherrington C, Lord SR, Close JC, Barraclough E, Taylor M, O'Rourke S, et al. A simple tool predicted probability of falling after aged care inpatient rehabilitation. J Clin Epidemiol. 2011;64(7):779-86.

70. Vivanti A, Ward N, Haines T. Nutritional status and associations with falls, balance, mobility and functionality during hospital admission. J Nutr Health Aging. 2011;15(5):388-91.

71. Chang CM, Chen MJ, Tsai CY, Ho LH, Hsieh HL, Chau YL, et al. Medical conditions and medications as risk factors of falls in the inpatient older people: a case-control study. Int J Geriatr Psychiatry. 2011;26(6):602-7.

72. Lee TT, Liu CY, Kuo YH, Mills ME, Fong JG, Hung C, et al. Application of data mining to the identification of critical factors in patient falls using a web-based reporting system. Int J Med Inform. 2011;80(2):141-50.

73. Costa S GRF, Monteiro DR, Hemesath MP, Almeida MA. Caracterização das quedas do leito sofridas por pacientes internados em um hospital universitário. Rev Gaúcha Enferm [Internet]. 2011 [citado 2013 Mar 2013];32(4):67681. Disponível em: http://www.scielo.br/pdf/rgenf/v32n4/ v32n4a06.pdf

74. Bakr IM, Abd Elaziz KM, Elgaafary MM, Kandil SK, Fahim HI. Epidemiologic pattern of falls among inpatients in Ain Shams University Hospitals in Cairo, Egypt. J Prev Med Hyg 2011;52(1):32-7.

75. Kelly A, Dowling M. Reducing the likelihood of falls in older people. Nurs Stand. 2004;18(49):33-40.

76. Schwendimann S, Geest SD, Milisen K. Evaluation of the Morse Fall Scale in hospitalized patients. Age Ageing [Internet]. 2006[cited 2013 Mar 13];35(3):311-3. Available from: http:// ageing.oxfordjournals.org/content/35/3/311.full.pdf+html

77. Schwendimann R, Geest S, Milisen K. Screening older patients at risk for falling during hospitalization. Int J Inj Contr Saf Promot. 2007;14(1):64-5.
78. Dykes PC, Carroll DL, Hurley AC, Benoit A, Middleton B. Why do patients in acute care hospitals fall? Can falls be prevented? J Nurs Adm [Internet]. 2009 [cited 2013 Mar 14];39(6):299-304. Available from: http://www.ncbi.nlm. nih.gov/pmc/articles/PMC3107706/pdf/nihms259498.pdf

79. Dykes PC, Carroll DL, Hurley A, Lipsitz S, Benoit A, Chang F, et al. Fall prevention in acute care hospitals: a randomized trial. JAMA. 2010;304(17):1912-8.

80. Webster J, Courtney M, Marsh N, Gale C, Abbott B, Mackenzie-Ross $A$, et al. The STRATIFY tool and clinical judgment were poor predictors of falling in an acute hospital setting. J Clin Epidemiol. 2010;63(1):109-13.

81. Bugdayci D, Paker N, Dere D, Özdemir E, Ince N. Frequency, features, and factors for falls in a group of subacute stroke patients hospitalized for rehabilitation in Istanbul. Arch Gerontol Geriatr. 2011;52(3):e215-9.

82. Johnson JE, Veneziano T, Green J, Howarth E, Malast T, Mastro K, et al. Breaking the fall. J Nurs Adm. 2011;41(12):538-45.

83. Ang E, Mordiffi SZ, Wong HB. Evaluating the use of a targeted multiple intervention strategy in reducing patient falls in an acute care hospital: a randomized controlled trial. J Adv Nurs. 2011;67(9):1984-92.

84. Tucker SJ, Bieber PL, Attlesey-Pries JM, Olson ME, Dierkhising RA. Outcomes and challenges in implementing hourly rounds to reduce falls in orthopedic units. Worldviews Evid Based Nurs. 2012;9(1):18-29.

85. Kohn LT, Corrignan JM, Donaldson MS. To err is human: building a safer health system. Washington: National Academy Press; 2001.

86. Brasil. Lei n. 9782, de 26 de janeiro de 1999. Define o Sistema Nacional de Vigilância Sanitária, cria a Agência Nacional de Vigilância Sanitária e dá outras providências [Internet]. Brasília; 1999 [citado 2013 mar. 14]. Disponível em: http:// www.planalto.gov.br/ccivil_03/leis/L9782.htm

87. Cassiani SHB. Enfermagem e a pesquisa sobre segurança dos pacientes [editorial]. Acta Paul Enferm. 2010;23(6):viii.

88. World Health Organization (WHO). World Alliance for Patient Safety. Forward Programme 2008-2009. Geneva: WHO; 2010.

89. Silva AEBC. Segurança do paciente: desafios para a prática e a investigação em Enfermagem. Rev Eletr Enferm [Internet]. 2010 [citado 2013 mar. 14];12(3). Disponível em: http:// www.fen.ufg.br/revista/v12/n3/v12n3a01.htm

90. Runciman $\mathrm{W}$, Hibbert $\mathrm{P}$, Thomson R, et al. Towards an International Classification for Patient Safety: key concepts and terms. Int J Qual Health Care. 2009;21(1):18-26. 
91. Matsuda LM, Silva DMP, Évora YDM, Coimbra JAH. Anotações/registros de enfermagem: instrumento de comunicação para a qualidade do cuidado? Rev Eletr Enferm [Internet]. 2006 [citado 2013 mar. 15];8(3):415-21. Disponível em: http://www.fen.ufg.br/revista/revista8_3/v8n3a12.htm

92. Morse JM, Morse RM, Tylko SJ. Development of a scale to identify the fall-prone patient. Can J Aging. 1989;8(4):366-77.

93. Morse JM, Black C, Oberle K, Donahue P. A prospective study to identify the fall prone patient. Soc Sci Med. 1989;28(1):81-86.

94. Ang NKE, Mordiffi SZ, Wong HB, Devi K, Evans D. Evaluation of three fall-risk assessment tools in an acute care setting. J Adv Nurs. 2007;60(4):427-35.

95. Oliver D, Britton M, Seed P, Martin FC, Hopper AH. Development and evaluation of evidence based risk assessment tool (STRATIFY) to predict which elderly inpatients will fall casecontrol and cohort studies. BMJ. 1997;315(7115):1049-53.
96. Hendrich AL, Bender PS, Nyhuis A. Validation of the Hendrich II Fall Risk Model: a large concurrent case/control study of hospitalized patients. Appl Nurs Res. 2003;16(1):9-21.

97. Vassallo M, Poynter L, Sharma JC, Kwan J, Allen SC. Fall riskassessment tools compared with clinical judgment: an evaluation in a rehabilitation ward. Age Ageing. 2008;37(3):277-81.

98. Machado TR, Oliveira CJ, Costa FBC, Araujo TL. Avaliação da presença de risco para queda em idosos. Rev Eletr Enferm [Internet]. 2009 [citado 2013 jan. 02];11(1):32-8. Disponível em: http://www.fen.ufg.br/revista/v11/n1/pdf/v11n1a04.pdf

99. Aiken LH, Clarke SP, Cheung RB, Sloane DM, Silber JH. Educational levels of hospital nurses and surgical patient mortality. JAMA. 2003;290(12):1617-23.

100. Lopes KT, Costa DF, Castro DP, Sloane DM, Silber JH. Prevalência do medo de cair em uma população de idosos da comunidade e sua correlação com mobilidade, equilíbrio dinâmico, risco e histórico de quedas. Rev Bras Fisioter. 2009;13(3):223-9. 